\title{
INVESTIGATIONS ON THE MODE OF ACTION OF D-6-METHYL-8-CYANOMETHYLERGOLINE IN SUPPRESSING PREGNANCY IN THE MOUSE
}

\author{
P. G. MANTLE AND G. A. FINN \\ Biochemistry Department, Imperial College, London, and \\ Physiology Department, Royal Veterinary College, London
}

(Received 6th October 1970)

Pregnancy in the rat can be prevented by a single intragastric administration of D-6-methyl-8-cyanomethylergoline (GME), a new synthetic ergoline derivative, during the first 7 days after mating (Režabek, Semonský \& Kucharczyk, 1969). This substance is structurally closely related to the naturally occurring alkaloid, agroclavine, which has been shown to prevent implantation in mice and rats (Mantle, 1969; Edwardson \& MacGregor, 1969).

In a preliminary experiment, following the technique (Režabek et al., 1969) successfully used in rats, CME (250 $\mu \mathrm{g}$ in $250 \mu \mathrm{l}$ of $1 \%$ tartaric acid) was administered to five mice by a single intragastric injection on each of the first 7 days of pregnancy. Eighteen out of thirty-five treated mice remained pregnant in comparison with twenty-three out of thirty-five untreated control mice. Thus, as there was no consistent evidence that implantation had been suppressed, it was concluded that the mouse was possibly less sensitive to a single intragastric administration of CME.

By contrast, daily administration of food $(5 \mathrm{~g})$ containing $250 \mu \mathrm{g}$ CME to groups of five mice during 3-day periods after mating (Days 1, 2 and 3; Days 3, 4 and 5; Days 5, 6 and 7) completely prevented pregnancy. The effect on the uterus in the immediate implantation period (Days 3,4 and 5) was similar to that previously observed in response to treatment with agroclavine (Mantle, 1969; Finn \& Mantle, 1969). In subsequent studies, therefore, CME was administered in the food.

A single day's treatment with CME on Day 1 did not affect the cellular changes which take place in the uterus just before implantation (Finn \& Martin, 1967) and pregnancy was not prevented (Tables 1 and 2). If, however, GME treatment was continued for two days, this resulted, as in those mice treated on Days 1, 2 and 3, in a failure of the uterine cellular changes characteristic of Day 4 of pregnancy. In spite of returning the CME-treated mice to a normal diet on Day 3, the effect of the alkaloid was not diminished and implantation did not take place.

Two days' treatment with GME postimplantation, starting on Day 6, elicited no macroscopic effect on pregnant uteri by Day 7, but resorption of all foetuses was evident in several animals by Day 9 (Table 1). Similar treatment beginning on Day 7 had no effect on pregnancy. 
TABLE 1

EFFEGT OF GME ON EARLY PREGNANCY IN MICE

\begin{tabular}{l|l|c|c|l}
\hline $\begin{array}{c}\text { CME } \\
\text { meal given* }\end{array}$ & \multicolumn{1}{|c|}{$\begin{array}{c}\text { Mice } \\
\text { killed }\end{array}$} & $\begin{array}{c}\text { No. of } \\
\text { animals }\end{array}$ & Pregnant & \multicolumn{1}{c}{$\begin{array}{c}\text { Condition of } \\
\text { pregnant uteri }\end{array}$} \\
\hline Day 1 & Parturition & 4 & 3 & Normal \\
Days 1 to 2 & Parturition & 4 & 0 & Normal \\
None & Parturition & 4 & 4 & Normal \\
Day 6 & Day 7 & 6 & 6 & Normal \\
None & Day 7 & 5 & 4 & Three normal; one early resorption \\
Days 6 to 7 & Day 8 & 5 & 4 & One normal; four resorption \\
Days 6 to 7 & Day 9 & 5 & 5 & Normal \\
Days 6 to 7 & Parturition & 6 & 2 & Normal \\
None & Day 9 & 5 & 4 & Normal \\
Days 7 to 8 & Parturition & 7 & 7 & Normal \\
None & Parturition & 6 & 6 & \\
\hline
\end{tabular}

* $5 \mathrm{mg} \mathrm{CME} / 100 \mathrm{~g}$ meal.(5 g/mouse/day up to Day $5,6 \mathrm{~g} /$ mouse/day from Day 6.)

TABLE 2

EFFEGT OF GME, WITH OR WITHOUT PROLAGTIN, ON GELL DIVISION IN THE UTERUS ON THE 4TH DAY OF PREGNANCY

\begin{tabular}{|c|c|c|c|c|}
\hline \multirow{3}{*}{ CME meal given* } & \multirow{3}{*}{$\begin{array}{c}\text { Noo. of } \\
\text { animals } \ddagger\end{array}$} & \multicolumn{3}{|c|}{ Mean no. of mitoses $\pm S . E}$. \\
\hline & & \multicolumn{2}{|c|}{ Epithelium } & \multirow{2}{*}{ Stroma } \\
\hline & & Lumen & Glands & \\
\hline $\begin{array}{l}\text { Day } 1 \\
\text { Days } 1 \text { and } 2 \\
\text { Days } 1,2 \text { and } 3 \\
\text { Days } 1 \text { and } 2 \\
+ \text { prolactin } \dagger \text { Days } 2,3 \text { and } 4\end{array}$ & $\begin{array}{l}4 \\
6 \\
4 \\
4\end{array}$ & $\begin{array}{l}0 \\
33 \stackrel{0}{ \pm 17 \cdot 5} \\
53 \cdot 2 \pm 23 \cdot 7 \\
0\end{array}$ & $\begin{array}{c}1 \pm 1 \\
28 \cdot 3 \pm 9 \cdot 0 \\
7 \cdot 5 \pm 3 \cdot 1 \\
0\end{array}$ & $\begin{array}{r}33 \cdot 5 \pm 4 \cdot 3 \\
10 \cdot 6 \pm 4 \cdot 7 \\
9 \cdot 7 \pm 1 \cdot 4 \\
23 \cdot 0 \pm 5 \cdot 6\end{array}$ \\
\hline
\end{tabular}

* $5 \mathrm{~g}$ of $5 \mathrm{mg} \mathrm{CME} / 100 \mathrm{~g}$ meal/day/mouse.

+12.5 i.u. subcutaneously morning and evening (NIH P-S-G ovine prolactin).

$\ddagger$ Killed $2 \mathrm{hr}$ after subcutaneous injection of Colcemid (0.1 mg) (Finn \& Martin, 1967).

TABLE 3

EFFECT ON PREGNANCY OF PROLACTIN REPLACEMENT THERAPY FOLLOWING PREGNANCY-SUPPRESSING TREATMENT WITH CME

\begin{tabular}{l|l|l|c|c}
\hline $\begin{array}{c}\text { CME } \\
\text { meal given* }\end{array}$ & \multicolumn{1}{|c|}{$\begin{array}{c}\text { Prolactin } \\
\text { givent }\end{array}$} & $\begin{array}{c}\text { Mice } \\
\text { killed }\end{array}$ & $\begin{array}{c}\text { No. of } \\
\text { animals }\end{array}$ & Pregnant \\
\hline Days 1 and 2 & Days 2 to 5 & Day 6 & 4 & 4 \\
Days 1 and 2 \\
Days 1 and 2 & None & Day 8 & 5 & 0 \\
Days 1 and 2 & Days 2 to 5 & Day 10 & 4 & 4 \\
None & Days 2 to 10 & Postparturition & 4 & 4 \\
None & Days 2 to 10 & Postparturition & 5 & 4 \\
\hline
\end{tabular}

* $5 \mathrm{~g}$ of $5 \mathrm{mg}$ CME/100 $\mathrm{g}$ meal/day/mouse.

$+12 \cdot 5$ i.u. subcutaneously morning and evening. 
The cellular changes in the uterus just before implantation are influenced by progesterone which is secreted from the corpora lutea under the control of pituitary prolactin. The pituitary is essential until about Day 7 of pregnancy when the placenta starts secreting a luteotrophic substance. Thus, the effects observed following CME treatment could be mediated through a block in the release of pituitary prolactin. To investigate this, the effect of exogenous ovine prolactin was tested (Tables 2 and 3). The total suppression of pregnancy by GME treatment on Days 1 and 2 was completely reversed by prolactin so that the usual preparation of the uterus for implantation occurred (Table 2) and normal pregnancy was established (Table 3). The ineffectiveness of CME treatment on Days 7 and 8 suggests that there is no effect on luteotrophin synthesis in the placenta but that the suppression of pregnancy at an earlier stage is mediated at the pituitary or hypothalamic level.

The effect of GME on the induction of pseudopregnancy was also investigated. Thirteen female mice were fed on the standard CME diet (250 $\mu \mathrm{g}$ CME/mouse/ day) for 2 days after mating with a vasectomized male. Eleven mice returned to oestrus on Day 4 or 5 . The immediate postcoital administration of GME apparently prevented pseudopregnancy, which in ten out of ten untreated control mice lasted for 10 to 12 days; a result in accord with the suppression of pituitary prolactin.

Recently, Seda, Režabek, Marhan \& Semonský (1971) have shown a gonadotrophic effect of CME on ovarian hypertrophy after unilateral ovariectomy and suggested that GME stimulates the hypothalamus to release FSH- and LHreleasing factors. The present results, by indicating the suppression of prolactin secretion, also support the possibility of a general hypothalamic stimulation. If there is a general stimulatory effect on the hypothalamus, the complete restoration of normal pregnancy by exogenous prolactin implies that the pregnancy-inhibiting effect of CME is mediated principally by an increase in prolactin-inhibiting factor.

In the mouse, CME appeared to have a more persistent action than agroclavine (Mantle, 1969). It is also less toxic and, being a dihydro-ergoline derivative, is more stable than agroclavine. It is suggested that, if the central effects of GME can be confirmed by more direct methods, this substance could become a useful tool in the study of the rôle of prolactin.

The generous supply of D-6-methyl-8-cyanomethylergoline by $\operatorname{Dr} \mathrm{M}$. Semonsky is gratefully acknowledged.

\section{REFERENCES}

Edwardson, J. A. \& MAcGregor, L. A. (1969) The effect of progesterone and some other agents on the failure of pregnancy produced by feeding agroclavine, an ergot alkaloid, in the rat. Br. $\mathcal{F}$. Pharmac. Chemother. 35, 367P.

Finn, C. A. \& MantLe, P. G. (1969) The influence of agroclavine on the preparation of the uterus for implantation in the mouse. 7 . Reprod. Fert. 20, 527.

Finn, C. A. \& Martin, L. (1967) Patterns of cell division in the mouse uterus during early pregnancy. 7. Endocr. 39, 593. 
Mantle, P. G. (1969) Interruption of early pregnancy in mice by oral administration of agroclavine and sclerotia of Claviceps fusiformis (Loveless). 7. Reprod. Fert. 18, 81 .

Režabex, K., Semonský, M. \& Kugharczyx, N. (1969) Suppression of conception with D-6-methyl8-cyanomethylergoline (I) in rats. Nature, Lond. 221, 666.

Seda, M., Režabek, K., Marhan, O. \& Semonský, M. (1971) Stimulation of gonadotrophin secretion with the pregnancy inhibitor D-6-methyl-8-cyanomethylergoline (I). J. Reprod. Fert. 24, 63. 